\title{
Bioremediation of wastewaters from local textile industries
}

\author{
Abdullahi Ajao *1 (iD), Sunday Awe
}

\begin{abstract}
The present study evaluates the bioremediation potential of indigenous bacterial species isolated from dyecontaminated soil samples from small dyeing outlet located in llorin. The water pollution index was estimated based on the physicochemical characteristics and heavy metal concentrations of the raw (Day 0$)$ and treated textile wastewater such as $\mathrm{pH}$, biochemical oxygen demand-5, chemical oxygen demand, total suspended solids and total dissolved solid with mean values of $8.85 \pm 0.45 \mathrm{mg} / \mathrm{L}, 1200 \pm 21.3 \mathrm{mg} / \mathrm{L}, 2440 \pm 31.3 \mathrm{mg} / \mathrm{L}, 1660 \pm 17.2$ $\mathrm{mg} / \mathrm{L}$ and $2650 \pm 28.1 \mathrm{mg} / \mathrm{L}$ respectively, similarly, Lead was the most abundant heavy metal detected in the sample while Cadmium concentration was the lowest with the mean values of $3.52 \pm 0.00 \mathrm{mg} / \mathrm{L}$ and $2.18 \pm 0.00$ $\mathrm{mg} / \mathrm{L}$ respectively. The bacterial strain with highest dye decolorization capacity was screened and identified as Bacillus licheniformis ZUL012. The isolate was consequently used for the bioremediation of the wastewater over a period of 10 days. The results showed an incredible reduction in the physiochemical characteristics and heavy metal concentrations of the textile wastewater in the following ranges (8.85-6.55), (1200-300) mg/L, (2440-518) $\mathrm{mg} / \mathrm{L},(1660-666) \mathrm{mg} / \mathrm{L}$ and (2650-920) $\mathrm{mg} / \mathrm{L}$ with the highest removal efficiency of $75 \%, 78 \%, 60 \%, 65 \%$, recorded for biochemical oxygen demand, chemical oxygen demand, total suspended solid, total dissolved solid, respectively while that of heavy metals such as lead, cadmium, chromium and nickel were $80 \%, 60 \%, 67 \%, 72$ $\%$ reduction, respectively. Laccase and Azoreductase activities tend to decrease as the $\mathrm{pH}$ gradually moved towards acidic condition during the bioremediation process. Toxicity of the treated effluent was assessed using Maize and Bean seed germination test. Conclusively, these research findings can serve as a framework for the outlet design of wastewater treatment plant for local textile outlets.
\end{abstract}

\section{Keywords}

Bacillus; Bioremediation; Enzymes; Fourier transformed infrared spectroscopy (FTIR); Gas chromatographymass spectrometry (GC-MS); Physicochemicals; Textile wastewater.

${ }^{1}$ Kwara State University

*Corresponding Author: abdullahi.ajao@kwasu.edu.ng

Manuscript received date: December 18, 2018

Accept Date: December 31, 2018

Published Date: December 31, 2018.

\section{INTRODUCTION}

Textile industries consume several million tons of synthetic dyes (around 56\%) of world total annual production (Adegoke and Bello, 2015; Markandeya et al., 2017). A large volume of water is needed during the operations in the textile industry thereby, generating a tremendous amount of wastewater containing a significant amount of unfixed dyes (Markadeya et al., 2017). Apparently, the indiscriminate discharge of such toxic wastewaters in and around the residential and industrial areas constitute major environmental and health hazard. Several illnesses, tumors, cancers, and various allergies have been linked to the Azo dyes content in textile wastewaters that are found to be toxic, mutagenic and recalcitrance in nature (Shah, 2018; Yaseen and Scholz, 2018) The complex aromatic structure of these dyes makes it recalcitrant to degradation and conventional treatment methods are found to be ineffective (Adegoke and Bello, 2015). The available strategies for the dyes containing wastewater treatment have been the physicochemical methods (Das et al., 2016; Shah, 2018). However, application of each of these strategies has been characterized with numerous shortcomings including large usage of chemical or sludge deposition with apparent disposal issues; expensive operating and plant requirement, ineffective in color reduction especially Azo dyes (Fayidh et al., 2011). Bioremediation is the application of microorganisms in the waste management system, which exploits 
microorganisms for the removal and recycling of pollutants in the environment (Endeshaw et al., 2017). Microorganisms with diverse catabolic versatility utilize organic pollutants as their energy source and break down those pollutants into non-toxic intermediate compounds. Bioremediation strategy is receiving more attention due to its cost- effectiveness, and diverse metabolic versatility of microorganisms involved (Pandey et al., 2007). The survival and adaptability of organisms in dye contaminated sites make them incredibly tolerant to the toxic effect of high dye concentrations; therefore can be used effectively for the bioremediation of colored effluent released from various fabric processing units (Ogugbue et al., 2012). Application of this approach on an industrial scale becomes difficult due to the complexity of dye constituents of textile wastewater. However, a continued search for the new organisms and technologies are required to make this process of bioremediation more industrially viable, cheap and ecofriendly remediation technology. Consequently, the present study was carried to investigate the bioremediation potential of indigenous bacteria towards bioremediation of local textile wastewater obtained from the local outlet. This study was undertaken in the Department of Microbiology, Kwara State University, Malete, Nigeria in $2017-2018$.

\section{Materials \& Methods}

\section{Sample collection}

The Local textile wastewater and soil contaminated with dye effluents were collected from small dyeing outlet situated within Ilorin metropolis, Kwara State, Nigeria in sterile screw-capped plastic containers, then transported to the Microbiology Laboratory, Malete for the experiment.

\section{Characterization of local textile wastewaters}

The Pollution load assessment of the local textile wastewater was investigated using physicochemical parameters and heavy metal concentrations namely Chemical Oxygen Demand (COD) Biological Oxygen Demand, Total Suspended Solid, Total Dissolved Solid and pH. Also, heavy metal concentrations such as Lead, Cadmium, Chromium, and Nickel were determined following standard methods (APHA, 1999). These parameters served as a measure of the pollution index, performance criteria and efficiency of the bioremediation process. The heavy metal pollution levels were analyzed using atomic adsorption spectrophotometer (AAS -model-GBC-932 plus Chem Tech-USA)

\section{Enrichment techniques and isolation of potential dye degrading bacteria}

Textile wastewater sample was enriched using a modified method of Olukanni et al, (2013). Aliquot of $5 \mathrm{~mL}$ soil suspension obtained from $10 \mathrm{~g}$ of dye polluted soil samples suspended in $100 \mathrm{ml}$ of sterile distilled water was added to the nutrient broth containing $10 \%$ of the sterilized textile effluents in $250 \mathrm{ml}$ Erlemeyer flasks, then kept at 30 0C for 48 hours in an orbital shaker at $150 \mathrm{rpm}$. One milliliter of the enriched bacterial culture was picked and serially diluted and inoculated on the nutrient agar plates. After $48 \mathrm{hr}$ of incubation, the morphologically distinct bacterial colonies further purified by repeated streaking on nutrient agar plates. The bacterial colony with high growth rate and decolorization potential was selected and identified based on the Gram reaction and biochemical test, then stored below $10^{\circ} \mathrm{C}$ on nutrient agar slopes for molecular Identification

\section{SrDNA sequences processing}

Genomic DNA of the isolate was extracted following standard method. PCR amplification was carried out as follows: A pair of universal primer of 27F (5-AGAGTTTGATCCTGGCTCAG-3) and 1492R (5- GGTTACCTTGTTACGACTT-3) was added to $2.5 \mu l$ PCR buffer containing $2 \mu l$ dNTP mix, $0.2 \mu l$ Taq DNA polymerase, $5 \mu l 3$ of DNA template and $12.8 \mu l$ sterile distilled water made up $25 \mu \mathrm{L}$ reaction volumes. The thermo-cycler PCR conditions were as follows: denaturation $\left(92^{\circ} \mathrm{C} / 1\right.$ $\mathrm{min})$, annealing $\left(54^{\circ} \mathrm{C} / 1 \mathrm{~min}\right)$ and extension $\left(72^{\circ} \mathrm{C} / 1 \mathrm{~min}\right)$ in 30 cycles (Miller et al., 2013). PCR product was loaded into well and electrophoresed on agarose gel at $120 \mathrm{~V}$ for 45 minutes using a maxi gel system. The band on the gels was visualized by ultraviolet trans-illumination (Uvitec, Cambridge, UK), then sequenced. The 16S rRNA sequences of the isolate and similar sequences downloaded from NCBI database using the BLAST search program were aligned using the multiple sequence alignment and dendrogram was generated using MEGA 6.0.

\section{Bioremediation process}

The dye degrading cell was grown in nutrient broth and incubated for 8 hours to attain exponential growth phase at the optical density (OD600 $\mathrm{nm}=1.0$ which correspond to $109 \mathrm{cfu} / \mathrm{ml}$ were used as inoculums. Fifty milliliters of the textile wastewater was added to the $150 \mathrm{ml}$ of nutrient broth in a $250 \mathrm{ml}$ Elmeyer flask and sterilized in an autoclave at $121^{\circ} \mathrm{C}$ for 15 minutes. It was allowed to cool, then inoculated with $20 \mathrm{ml}$ of the inoculums, incubated at $30^{\circ} \mathrm{C}$ on a rotary shaker at $120 \mathrm{rpm}$ for 10 days. Six different setups were made. Physicochemical parameters, enzymatic activities, Extracellular proteins, and Total viable counts were determined at 48-hour intervals from the experimental flasks over a period of 10 days to monitor the progress of the treatment. Fourier transformed infrared spectroscopy (FTIR); Gas chromatography-mass spectrometry (GC-MS) was used for the confirmation of the biodegradation process 


\section{Fourier transformed infrared spectroscopy (FTIR) analysis}

The experimental setup of both the control and treated samples were investigated to assess the functional groups in both samples. The samples were centrifuged at 4000rpm for $20 \mathrm{~min}$. The residual dyes in the wastewater were extracted with Ethyl acetate, One $\mu l$ of sample was run in FTIR using KBr pellets, JASCO FT/IR 4100 generated an infrared spectral at 400-4000/cm scanning range.

\section{Gas chromatography-mass spectroscopy}

The number and the chemical constituents of both treated and control local textile wastewater were determined using the Gas chromatography-mass spectroscopy (GC-MS). A 10-day treated wastewater and control samples were centrifuged at 8,944 $\times \mathrm{g}$ for $10 \mathrm{~min}$ and then extracted with ethyl acetate in a separating funnel, dried in a rotary evaporator and re-dissolved in high analytical grade methanol for GC-MS analyses.

\section{Enzymatic assay and growth patterns}

Enzyme Assay was carried out to determine the expression of Laccase and Azoreductase activities in the experimental flasks during the bioremediation process. The spectrophotometric method of Collins and Dobson (1997) was adopted for the determination of laccase activities while; Azoreductase activity was determined using the method of Leelakriangsak and Borisut, (2012). Bradford's method was used for the estimation of protein Content as described by Singh and Abraham (2013). Total Viable counts were estimated carrying out serial dilution method and pour plate method (Fawole and Oso, 2001).

\section{Seed germination assay}

The toxicity of both treated and control samples was investigated using seed germination test, this test measured the impact of the textile wastewater on the crops as well as to assert the possible reuse of the treated wastewater for the irrigation of agricultural fields after bioremediation. The experiment was carried out in Petri dishes whose top and bottom was padded with a layer of tissue paper as follows; Each of the padded Petri dishes contained 20 seeds each of maize and beans separately which were soaked with $25 \mathrm{ml}$ of treated and distilled water used as the control. The set-up was incubated for 7 days for germination to occur. The percentage of seed germination was calculated using Eq. 1.

$$
\text { Germination }(\%)=\frac{\text { Numberofseedsgerminated } \times 100}{\text { Totalnumberofseeds }}
$$

\section{Data entry and analysis}

The means values of the physicochemical parameters and heavy metal concentration of the textile wastewater samples were shown in Tables. The mean values of the data obtained during growth patterns and enzymatic activities were analyzed using One-way ANOVA, where there were differences between the means, post hoc test was carried out using Duncan multiple range tests to rank the mean values. Level of significance was set at $p \leq 0.05$.

Table 1. Bioremediation of textile wastewater by Bacillus licheniformis ZUL012

\begin{tabular}{|c|c|c|c|c|c|c|c|}
\hline \multirow{2}{*}{ Parameter } & \multicolumn{6}{|c|}{ Period of degradation (Days) } & \multirow{2}{*}{$\begin{array}{l}\text { Efficiency } \\
(\%)\end{array}$} \\
\hline & $0 ?$ & 2 & 4 & 6 & 8 & 10 & \\
\hline $\mathrm{pH}$ & $8.85 \pm 0.45$ & $7.80 \pm 0.10$ & $8.00 \pm 0.00$ & $7.20 \pm 0.45$ & $6.85 \pm 0.00$ & $6.55 \pm 0.34$ & NA \\
\hline BOD5 (mg/L) & $1200.0 \pm 21.3$ & $950.0 \pm 6.7$ & $820.0 \pm 8.8$ & $768.0 \pm 5.3$ & $552.0 \pm 5.9$ & $300.00 \pm 15.6$ & 75 \\
\hline $\mathrm{COD}(\mathrm{mg} / \mathrm{L})$ & $2440.0 \pm 31.3$ & $1450.0 \pm 11.0$ & $1260.0 \pm 16.1$ & $983.0 \pm 12.4$ & $718.0 \pm 9.0$ & $518.0 \pm 7.6$ & 78 \\
\hline TSS (mg/L) & $1660.0 \pm 17.2$ & $1550.0 \pm 18.2$ & $1360.0 \pm 12.7$ & $1120.0 \pm 10.2$ & $892.0 \pm 8.2$ & $666.0 \pm 12.9$ & 60 \\
\hline TDS (mg/L) & $2650.0 \pm 28.1$ & $2160.0 \pm 30.7$ & $1786.0 \pm 21.9$ & $1442.0 \pm 14.1$ & $1176.0 \pm 12.5$ & $920.0 \pm 13.1$ & 65 \\
\hline $\mathrm{Pb}(\mathrm{mg} / \mathrm{L})$ & $3.12 \pm 0.55$ & $3.00 \pm 0.00$ & $2.87 \pm 0.00$ & $2.02 \pm 0.00$ & $1.92 \pm 0.00$ & $1.88 \pm 0.00$ & 80 \\
\hline $\mathrm{Cd}(\mathrm{mg} / \mathrm{L})$ & $2.18 \pm 0.00$ & $2.04 \pm 0.03$ & $1.96 \pm 0.00$ & $1.58 \pm 0.00$ & $1.20 \pm 0.02$ & $0.86 \pm 0.03$ & 60 \\
\hline $\mathrm{Cr}(\mathrm{mg} / \mathrm{L})$ & $3.20 \pm 0.23$ & $3.06 \pm 0.00$ & $2.64 \pm 0.04$ & $2.10 \pm 0.05$ & $1.67 \pm 0.00$ & $1.06 \pm 0.00$ & 67 \\
\hline $\mathrm{Ni}(\mathrm{mg} / \mathrm{L})$ & $3.52 \pm 0.00$ & $3.11 \pm 0.08$ & $2.74 \pm 0.07$ & $2.03 \pm 0.00$ & $1.76 \pm 0.06$ & $1.00 \pm 0.00$ & 72 \\
\hline \multicolumn{8}{|c|}{$\mathrm{pH}=$ Potential of Hydrogen; BOD = Biological Oxygen Demand; TSS = Total Suspended Solids; NA=Not Applicable } \\
\hline
\end{tabular}




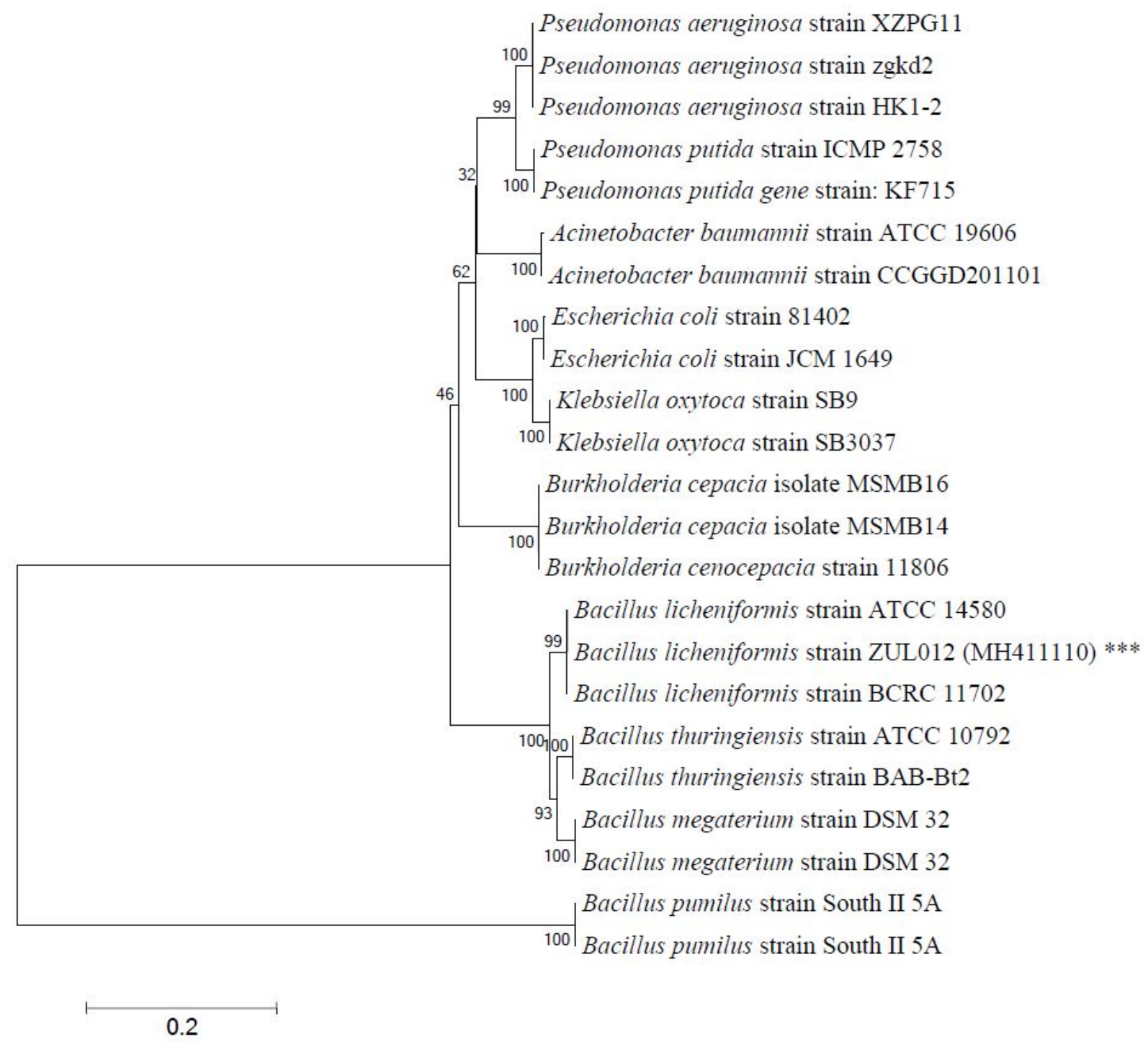

Figure 1. Constructed Phylogenetic tree of the partial 16S rDNA sequences using Neighbor-Joining method. The scale bar corresponds to 0.2 changes per nucleotide. Numbers in parenthesis and asteriks represent GenBank accession numbers.

Table 2. Growth Patterns and Enzymatic Activities during Bioremediation of Local Textile wastewater by Bacillus licheniformis ZUL012

\begin{tabular}{|l|l|l|l|l|l|}
\hline \multirow{2}{*}{ Parameter } & \multicolumn{5}{c|}{ Period of degradation (Days) } \\
\cline { 2 - 6 } & \multicolumn{1}{|c|}{2} & 4 & 6 & 8 & 10 \\
\hline $\mathrm{pH}$ & $8.65 \pm 1.15 \mathrm{a}$ & $8.00 \pm 0.81 \mathrm{a}$ & $7.12 \pm 0.05 \mathrm{a}$ & $7.65 \pm 1.15 \mathrm{~b}$ & $6.55 \pm 0.31 \mathrm{c}$ \\
\hline $\begin{array}{l}\text { Extracellular } \\
\text { protein } \\
(\mathrm{mg})\end{array}$ & $12.60 .0 \pm 1.42 \mathrm{~b}$ & $17.86 \pm 2.49 \mathrm{a}$ & $14.26 \pm 1.33 \mathrm{ab}$ & $11.55 \pm 1.62 \mathrm{~b}$ & $7.425 \pm 0.00 \mathrm{c}$ \\
\hline $\begin{array}{l}\text { Laccase } \\
\text { activities } \\
(\mathrm{U} / \mathrm{mg})\end{array}$ & $1.821 \pm 0.10 \mathrm{a}$ & $1.726 \pm 0.22 \mathrm{a}$ & $0.735 \pm 0.00 \mathrm{~b}$ & $0.551 \pm 0.11 \mathrm{c}$ & $0.346 \pm 0.00 \mathrm{~d}$ \\
\hline $\begin{array}{l}\text { Azo-reductase } \\
\text { activities (U/mg) }\end{array}$ & $2.00 \pm 0.12 \mathrm{a}$ & $2.107 \pm 0.21 \mathrm{a}$ & $1.980 \pm 0.00 \mathrm{ab}$ & $1.426 \pm 0.32 \mathrm{~b}$ & $1.130 \pm 0.00 \mathrm{bc}$ \\
\hline $\begin{array}{l}\text { TVC } \\
(\text { Log cfu/ml) }\end{array}$ & 3.65 & 4.75 & 6.41 & 5.54 & 5.94 \\
\hline
\end{tabular}




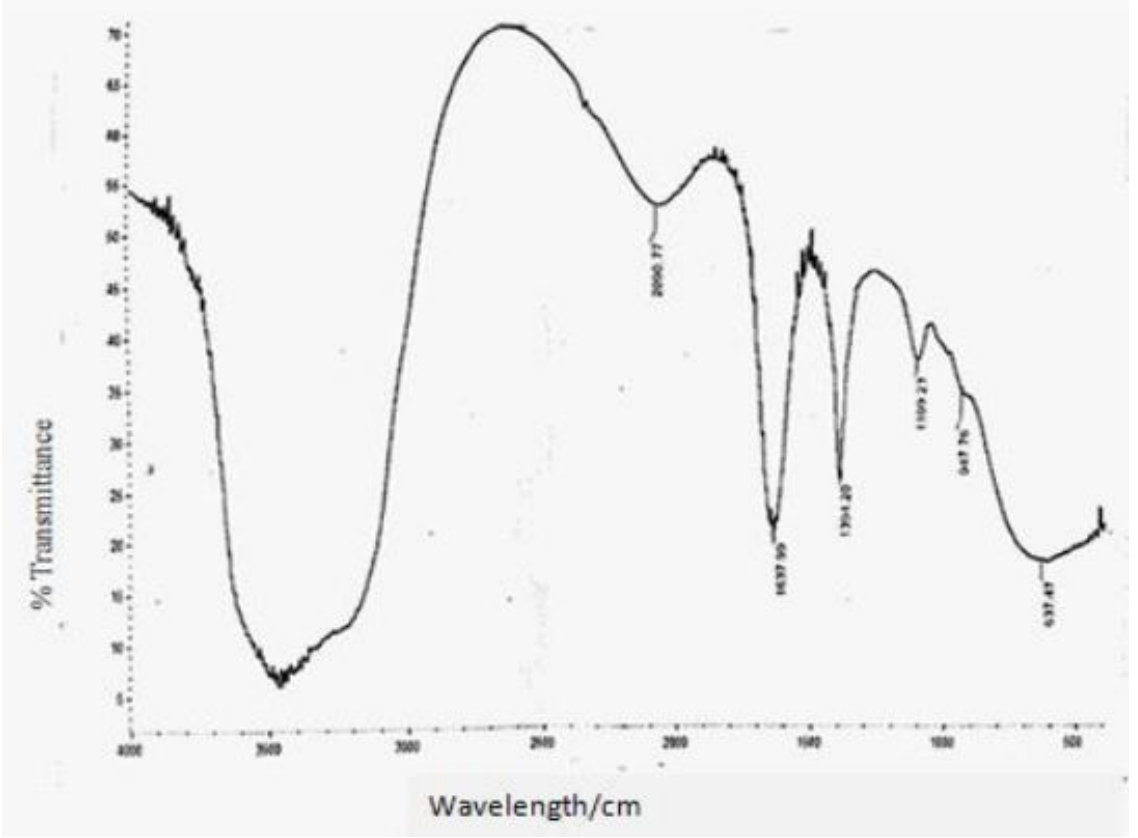

Figure 2. FTIR spectra of local textile wastewater (Control)

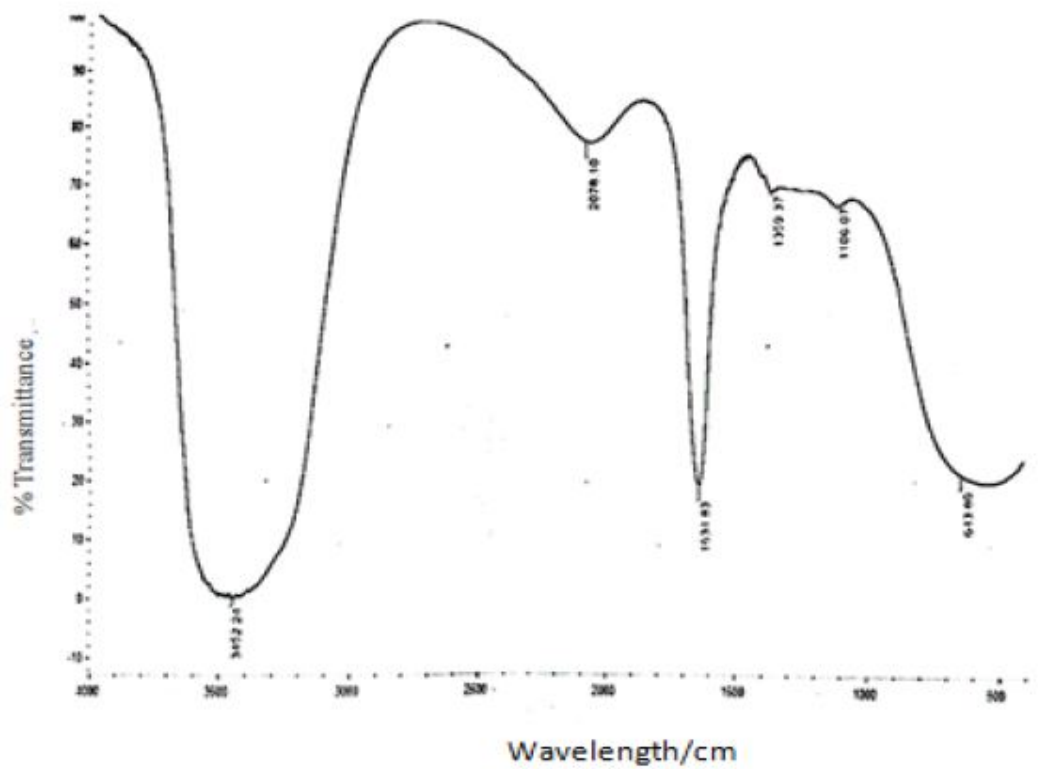

Figure 3. FTIR spectra of local textile wastewater Treated with Bacillus licheniformis Zul 012 


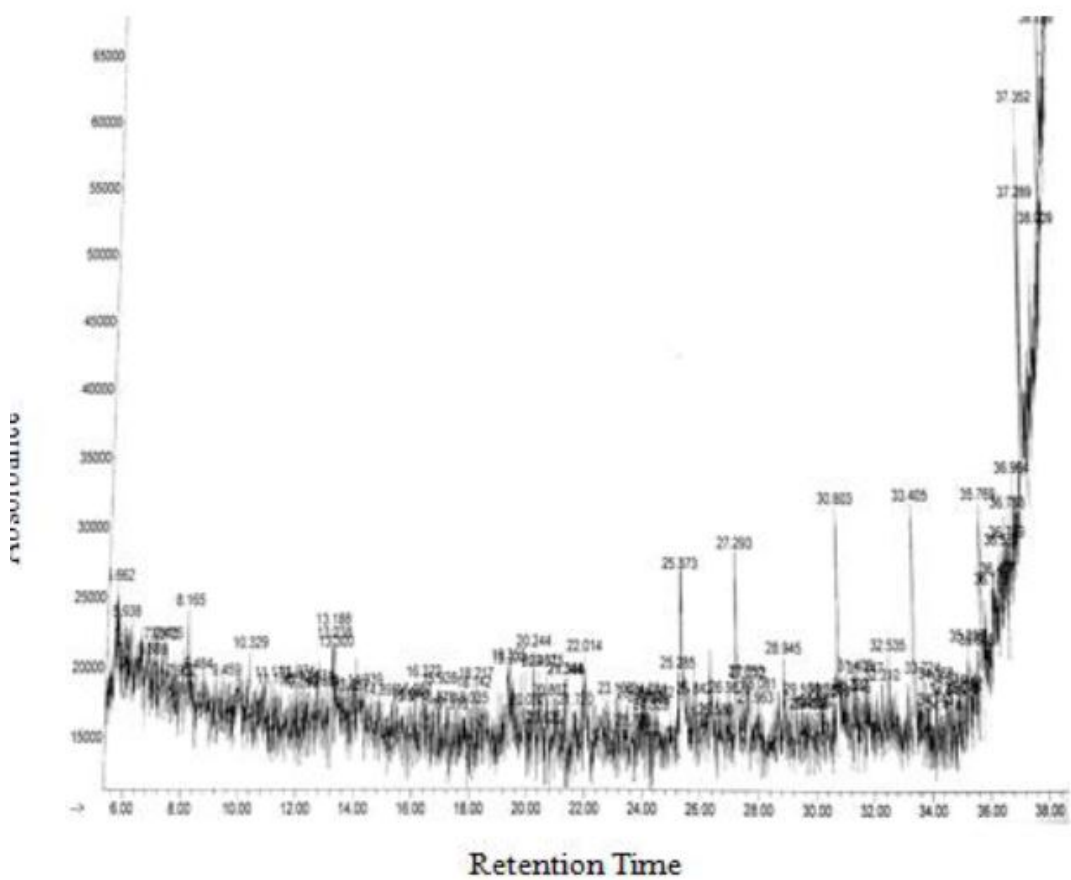

Figure 4. Chromatogram analysis of local textile wastewater (control)

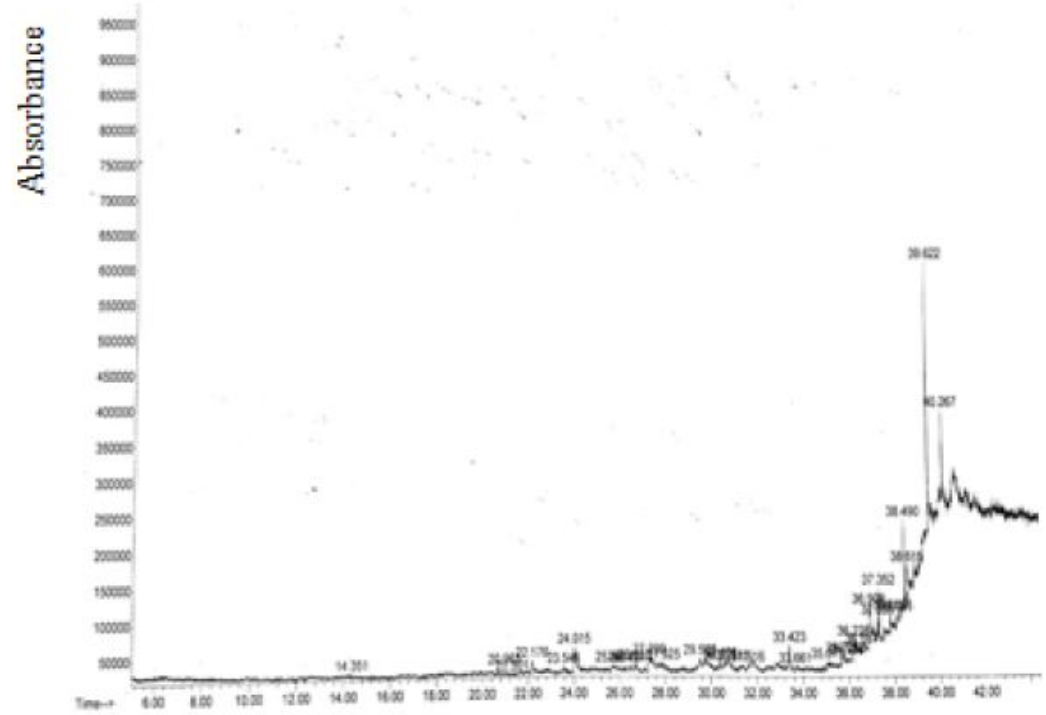

Retention Time

Figure 5. Chromatogram analysis of Local Textile wastewater Treated with Bacillus licheniformis ZUL012

\section{Results}

The wastewater from the local textile outlets was characterized by its following parameters; pH, BOD5, COD, TDS and TSS Likewise heavy metal concentrations. The mean values of the parameters of both untreated (raw) and the treated wastewater are shown in Table 1.The values of the parameters obtained are designated as Day 0. While the values recorded at 2- day interval for a 10-day treatment are presented as period of degradation (2-10 days). High values recorded for all the parameters underscored its degree of contamination and pollution load index. (Table 1) The initial $\mathrm{pH}$ of the sample at day 0 was found to be slightly alkaline with $\mathrm{pH}$ of 8.85 . Similarly, the total dissolved solids and total suspended solids recorded were $2650 \mathrm{mg} / \mathrm{L}$ and $1660 \mathrm{mg} / \mathrm{L}$ respectively, above the discharge limit of $787 \mathrm{mg} / \mathrm{L}$ and $574 \mathrm{mg} / \mathrm{L}$ (APHA, 2005), which can be attributed to the presence of synthetic dyes and other chemical constituents of the wastewater samples (Mohabansi et al., 2011). Similar results of high TDS in textile effluents had been reported by Paul et al. (2012). The COD and BOD levels were higher than the 
permissible limit; this underlined the oxygen-depletion properties of the wastewater. The heavy metal concentrations were recorded in the following ranges: Cadmium $(2.18 \mathrm{mg} / \mathrm{L})$, Lead (3.12 mg/L), Chromium (3.20 mg/L) and Nickel (3.52 mg/L). This was in the same order of magnitude as reported by Naeem et al. (2009). The major sources of heavy metals in textile wastewater include types of dyestuff, chemicals and even the water used during different stages of textile production as such heavy metal toxicity may affect soil fertility, microbial population size, diversity and activity (Ayansina and Olubukola, 2017). Especially when released into the environment without proper treatment.

The overall findings of the physicochemical characteristics and heavy metal ion concentrations of the textile wastewater demonstrated the high pollution index of the wastewater which in line with what was obtained in the similar study both in Nigeria and India (Awomeso et al., 2010; Vigneshpriya and Shanthi, 2015). Bacillus licheniformis strain Zul012 isolated in this study was explored for the bioremediation process. The isolate showed significant reduction in all the selected physicochemical characteristics and metal ion concentrations (Table 1). The initial $\mathrm{pH}$ of the sample before treatment was 8.85 which were changed to slightly acidic with the mean $\mathrm{pH}$ values of 6.55 . B. licheniformis strain Zul012 showed remarkable reduction in BOD5 (1200-300) mg/L, COD (2440-518) mg/L, TSS (1660-666) mg/L and TDS (2650-920) mg/L with the highest removal efficiency of $75 \%, 78 \%, 60 \%$ and $65 \%$ respectively after 10 days of treatment. Many studies have validated the successful applications of different Bacillus spp for the bioremediation of textile effluents (Kayode-Isola et al. 2008; Prasad et al. 2010; Usman et al. 2012; Ogunjobi et al. 2012). Apparently, Bacillus spp have proven to poses metabolic and enzymatic capacity to degrade textile wastes. The removal of TSS, TDS, COD and BOD observed in this study agreed with the findings of Prasad and Bhaskara (2010); Ajao et al. (2011) and Samuel et al. (2011). This remarkable reduction of all the contaminants observed after bioremediation agreed with the findings of Ranjamohan and Karthikayam (2004); Salisu and Mustapha (2010); Ajao et al. (2011) who reported high degree of reduction in BOD having 97\%, TSS (85\%), TDS and (96\%) by Bacillus megaterium, Pseudomonas aeruginosa and Alcaligenes faecalis to the regulatory acceptable limit. The current findings showed that Bacillus licheniformis ZUL012 demonstrated high biosorption capacity for some selected heavy metals in this order (Pb from 3.12 to $1.88 \mathrm{mg} / \mathrm{L}$ representing $80 \%, \mathrm{Cd}$ from 2.18 to $0.86 \mathrm{mg} / \mathrm{L}$ representing $60 \%$, $\mathrm{Cr}$ from 3.20 to $1.06 \mathrm{mg} / \mathrm{L}$ representing $67 \%$ and Ni from 3.52 to $1.00 \mathrm{mg} / \mathrm{L}$ representing 72\%) similar to the work of Wang et al. (2010); Ajao et al., 2011; Mathiyazhagan et al. (2011) Though, there was a variance in the metal-adsorption capacity to specific metals observed in this current study. The phylogenetic tree of Bacillus licheniformis 16S rDNA sequences and related bacterial sequences was represented is shown in Fig. 1. Biodegradation efficiency of the isolate can be attributed to the adaptability and acclimatization of the Bacillus licheniformis to the dye contaminated soil. This isolate might have probably acquired natural adaptation or through horizontal gene transfer to surviving and acquired the genes involved in the degradation of dyes. Bacillus spp posses high decolorization potential and ability to recondition the physicochemical properties of the textile wastewater (Srinivasan et al., 2014). Nutrient broth supplemented with the textile wastewater used as biodegradation broth in this study contained beef extract, yeast extract and peptone that might have served as primary substrate in the co-metabolism of textile effluent, which might have accounted for the remarkable degradation efficiency of the B. licheniformis (Mahmood et al., 2015) achieved in this study. Some Authors had also reported that yeast extract, sucrose, maltose, and sodium carbonate are commonly added as co-substrate for efficient textile effluents decolorisation by bacterial species which may, therefore, be regarded as cometabolism (Moosvi et al., 2007; Saratale et al., 2009; Elisangela et al., 2009; Mahmood et al., 2015). The pH, extracellular protein content, laccase activities, azoreductase activities, and total viable counts were used as surrogate indicators for monitoring the performance and evidence of bioremediation process (Table 3). The laccase activities, extracellular protein and azoreductase activities were found to be $\mathrm{pH}$ dependent, as they tend to decrease as $\mathrm{pH}$ gradually moved towards acidic. This finding suggests that alkaline $\mathrm{pH}$ tends to favor the growth and enzyme production (Rajeswari and Bhuvaneswari, 2016).However, since decolorization is not synonymous to detoxification, similarly, GC-MS and FTIR cannot be used to measure the toxicity of the end products, therefore, Assessment of the toxicity of the degradation products was evaluated (Bilal et al., 2016). Since the treated effluent will eventually be released into the river or soil, toxicity impact of those degradation products on the crops as a measure of treatment efficiency of the bioremediation process was determined (Saratale et al., 2009; Jadhav et al., 2010). Several infrared spectral detected both in the control and treated samples represent fingerprints with absorption peaks presented in Figs. 2 and 3 respectively. Six peaks were conspicuously observed from the spectra at the frequency region between 500-4000/cm with stretching type of vibrations at low and high peaks of the spectrum. Similarly, some functional groups were not detected in the treated textile wastewater. Peaks of the fingerprint region $(500$ to $1500 / \mathrm{cm})$ indicate the mono-substituted and para-disubstituted benzene rings representing aromatic metabolites in the samples. The spectrum at a peak of 643.80 and $650 / \mathrm{cm}$ represent strong $\mathrm{C}$-Br stretching, halo compound. A peak of 1106.07 and 1000/cm represent strong C-O stretching, secondary alcohol. A peak of 1359.37 and $1400 / \mathrm{cm}$ indicates strong $\mathrm{S}=\mathrm{O}$ stretching, sulfonamide. While a peak of 1634.83 and $1600 / \mathrm{cm}$ connote strong $\mathrm{C}=\mathrm{C}$ stretching monosubstituted alkene. A peak of 2078.10 at $2050 / \mathrm{cm}$ for strong $\mathrm{N}=\mathrm{C}=\mathrm{S}$ stretching isothiocyanate. A peak of 3452.24 and $3450 / \mathrm{cm}$ indicate strong O-H stretching intermolecular bonded alcohol was detected. However, some functional groups were not detected in the treated dye which can be attributed to the degradation of some metabolites present in the control samples. The chromatogram of both the control and treated textile effluent is shown in Fig. 4 and 5. The fragmentation patterns 
and mass per charges $(\mathrm{m} / \mathrm{z})$ values obtained from GC chromatogram and mass spectra were used to assign the structures and nomenclature of the compounds detected both in the treated and control wastewater samples represented by peaks. Each peak represents a compound. A number of peaks in the control samples found to be higher than in the treated samples this validates the degradation of the compounds in the treated samples during bioremediation. However, degradation is not synonymous with detoxification; therefore, phytotoxicity assessment of both treated and control local wastewater samples indicated that the seed watered with non-treated textile samples showed a tremendous toxic effect on both maize and beans seed germination. In contrast, treated dyes reduced the toxic effect of the effluents on the seed germination rate.

\section{Conclusion}

The main outcome of this work is the isolation of novel bacterial strain from the soil contaminated with textile wastewater that can effectively degrade local textile wastewater. Isolated bacterial species showed high dye degradation potential. Therefore this study demonstrates the successful utilization of pure culture of Bacillus licheniformis ZUL012 for the decolorization of local textile wastewater. Interestingly, the evidence for bacterial bioremediation of effluent from textile wastewaters was established. The reduction in BOD, COD, TSS, TDS, and biosorption of metal ions in a varying magnitude are appreciable. The removal efficiency in the level of pollutants and heavy metal biosorption paved way for the adoption of this bacterial sp for the treatment of textile wastewater in large scale.

\section{Acknowledgement}

Authors express their gratitude to the Management of Kwara State University, Malete for providing necessary facilities for the successful completion of this work.

\section{References}

Adegoke, K.; Bello, O.S., (2015). Dye sequestering using agricultural wastes as adsorbents. Water Resour. Ind., 12 : 8-24.

Ajao, A.T.; Adebayo, G.B.; Yakubu, S.E., (2011). Bioremediation of textile industrial effluent using mixed culture of Pseudomonas aeruginosa and Bacillus subtilis immobilized on agar agar in a Bioreactor. J. Microbiol. Biotech. Res., 1(3): $50-56$.

APHA (2005) Standard Methods for the Examination of Water and Wastewater. 21st Edition, American Public Health Association/American Water Works Association/Water Environment Federation, Washington DC., USA.

Awomeso, J.A.; Taiwo, A.M..; Gbadebo, A.M.; Adenowo, J.A., (2010). Studies on the pollution of waterbody by textile Industry effluents in Lagos, Nigeria. J. Appl. Sci. Environ. Sanit, 5: 353-359.

Ayansina S. A.; Olubukola, O. B., (2017) Review A New Strategy for Heavy Metal Polluted Environments: A Review of Microbial Biosorbents. Int. J. Environ. Res. Public Health, 14: 94

Bilal, M.; Iqbal, M.; Hu, H.; Zhang, X., (2016). Mutagenicity and cytotoxicity assessment of biodegraded textile effluent by Ca-alginate encapsulated manganese peroxidase. Biochem. Eng. J., (3):1010-1016.

Collins, P. J.; Dobson, A. D. W., (1997). Regulation of laccase gene transcription in Trametes versicolor. Appl. Environ. Microbiol., 63: 3444-3450.

Das, A.; Mishra, S., (2016). Decolorization of different textile azo dyes using an isolated Enterococcus durrans GM13. Int. J. Curr. Microbiol. App. Sci., 5(7): 676-686.

Elisangela, F.; Rea, Z.; Fabio, D.G.; Cristiano, R.M.; Regina, D.L., (2009). Biodegradation of textile azo dyes by a facultative Staphylococcus arlettae strain VN-11 using a sequential microaerophilic/aerobic process. Int. Biodeter. Biodegr., 63:280-288.

Endeshaw, A.; Birhanu, G.; Zerihun, T.; Misganaw, W., (2017) Application of microorganisms in bioremediation-review J. Environ. Microb., 1(1): 2-9.

Fawole, M.O.; Oso, B.A., (2001). Laboratory Manual of Microbiology. Revised Edition, Spectrum Books, Ibadan. Kaushik, 
G.; Thakur, I.S., (2014). Production of laccase and optimization of its production by Bacillus sp. using distillery spent wash as inducer. Bioremediat. J., 18: 28-37.

Kayode-Isola, T.M.; Eniola, K. I. T.; Olayemi A.B.; Igunnugbemi, O.O., (2008). Response of Resident Bacteria of a Crude Oil-Polluted River to Diesel Oil. Amer- Eura. J. Agr., 1:06-09.

Mahmood, S.; Khalid, A.; Mahmood, T.; Arshad, M.; Ahmad, R., (2015). Potential of newly isolated bacterial strains for simultaneous removal of hexavalent chromium and reactive black-5 azo dye from tannery effluent. J. Chem. Technol. Biotechnol., 88(8): 1506-1513.

Markandeya , T.; Shukla, S.P.; Mohan, D., (2017). Toxicity of Disperse Dyes and its Removal from Wastewater Using Various Adsorbents: A Review: Res. J. Environ. Toxic., 11: 72-89.

Mathiyazhagan, N.; Natarajan, D., (2011). Bioremediation of effluent from magnesite and bauxites and textile mine using Thiobacillus spp and Pseudomonas spp. J. Bioremed. Biodegrad., 2:115. doi: 10.4172/2155-6199.1000115.

Miller, C.S.; Handley, K.M.; Wrighton, K.C.; Frischkorn, K.R.; Thomas, B.C.; Banfield, J.F., (2013). Short-read assembly of full-length 16S amplicons reveals bacterial diversity in subsurface sediments. PloS one 2013: 8(2):e56018.

Leelakriangsak, M.; Borisut, S., (2012) Characterization of the decolorizing activity of azo dyes by Bacillus subtilis azoreductase AzoR1. Song. J. Sci. Technol., 34 (5): 509-516.

Moosvi, S.; Kher, X.; Madamwar, D., (2007). Isolation, characterization and decolorization of textile dyes by a mixed bacterial consortium JW-2. Dyes Pigm., 74: 723-729.

Ogunjobi, A.A.; Oyinloye, I.A.; Sanuth, H.A., (2012). Bioremediation of effluent from local textile industry using Bacillus licheniformis. N.Y. Sci. J., 5(12): 29-33.

Olukanni, D.O.; Osuntoki, A.A.; Awotula, A.O.; Kalyani, D.C.; Gbenle, G.O.; Govindwar, S.P., (2013). Decolorization of dye house effluent and biodegradation of Congo Red by Bacillus thuringiensis RUN1. J.M.B., 23(6): 843-84.

Pandey, A.; Singh, P.; Iyengar, L., (2007). Bacterial decolourisation and degradation of azo dyes. Int. Biodeterio. Biodegrad., (59): 73-84.

Prasad, A.S.; Bhaskara, K.V., (2010). Physico-chemical characterization of textile effluents and screening for dye decolourizing Bacteria. Global J. Biotechno. Biochem., 5 : (2): 55-62.

Rajamohan, N.; Karthikeyan, C., (2004). Fungi Biodegradation of Dye house Effluent and Kinetic Modeling' Department of Chemical Engineering, Annamalai University, Annamalainagar, Tamilnadu-India.

Rajeswari, M.; Bhuvaneswari, V., (2016). Production of extracellular laccase from the newly isolated Bacillus sp. PK4. Afr. J. Biotechno., 15(34): 1813-1826.

Salisu, D.; Mustapha, H.B., (2010). Industrial Pollution and Implication on Source of Water Supply in Kano, Nigeria. Int. J. Eng. Technol., 10: 1-32.

Samuel, E.A.; Ayobami, O. A., (2011). Evaluation of microbial system for bio-treatment of textile waste effluent in Nigeria. Biodecolourisation and Biodegradation of textile dye. JASEM., 15(1): 79-86.

Saratale, R.G.; Saratale, G,D.; Kalyani, D.C.; Chang, J.S.; Govindwar, S.P., (2009). Enhanced decolorization and biodegradation of textile azo dye Scarlet R by using developed microbial consortium-GR. Bioresour. Technol., 100: 2493-2500.

Saratale, R.G.; Saratale, G.D.; Chang, J. S.; Govindwar, S.P., (2011). Bacterial decolorization and degradation of azo dyes: a review. J. Taiwan Inst. Chem. Eng., 42:138-157. 
Shah, M.P., (2018). Bioremediation-Wastewater Treatment. J. Bioremediat. Biodegrad., 9: 427.

Singh, G.; Ahuja, N.; Sharma, P.; Capalash, N., (2009). Response surface methodology for the optimized production of an alkalophilic laccase from $\gamma$-proteobacterium JB. BioRes., 4(2): 544-553.

Singh, R.P.; Singh, P.K.; Singh, R.L., (2014). Bacterial Decolorization of textile azo dye Acid Orange by Staphylococcus hominis RMLRT03. Toxicol. Int., 21:160-166.

Sondhi, S.; Sharma, P.; George, N.; Chauhan, P. S.; Puri, N.; Gupta, N., (2014). An extracellular thermo-alkai-stable laccase from Bacillus tequilensis SN4, with a potential to biobleach softwood pulp. 3 Biotech., 5(2): 175-185.

Srinivasan, V.; Bhavan, S.P.; Krishnakumar, J., (2014). Bioremediation of textile dye effluent by Bacillus and Pseudomonas spp. Int. J. Sci. Environ. Techn., 3(6): 2215-2224.

Sriram, N.; Reetha, D.; Saranraj, P., (2013). Biological Degradation of Reactive Dyes by Using Bacteria Isolated from Dye Effluent Contaminated Soil. Middle-East J. Sci. Res., 17(12): 1695-1700.

Usman, D.H.; Ibrahim, A.; Abdullahi S., (2012). Potentials of Bacterial isolates in Bioremediation of Petroleum Refinery and effluent Wastewater. J. Appl. Phytotechn. Environ. Sanit., 1(3): 131-138.

Vigneshpriya, D; Shanthi, E., (2015). Physicochemical characterization of textile wastewater. Int. J. Innov. Res. Develop., 4(10): 236.

Yaseen, D.A.; Scholz, M., (2017). Comparison of experimental ponds for the treatment of dye wastewater under controlled and semi-natural conditions. Environ. Sci. Poll. Res., 24(19): 16031-16040.

Wang, F.; Yao, J.; Si, Y.; Chen, H.; Russel, M., (2010). Short time effect of heavy metals in soil microbes. Soil Microb. Biochem., 41: 2031-2037. 